\title{
Sentidos da voz em discursos da imprensa brasileira: uma análise de textos midiáticos sobre 0 câncer de laringe de Lula ${ }^{1 *}$
}

\section{Meanings of voice in the discourses of the Brazilian press: an analysis of the texts of media on Lula's throat cancer}

\section{Carlos Piovezani}

Universidade Federal de São Carlos (UFSCar), São Carlos, São Paulo, Brasil.

cpiovezani@uol.com.br

Resumo: O presente artigo analisa discursos produzidos pela mídia brasileira sobre o câncer de laringe sofrido pelo ex-presidente Luiz Inácio Lula da Silva em 2011. O anúncio da doença de Lula produziu um amplo conjunto de textos acerca da enfermidade e dos riscos que ela poderia acarretar à sua voz. Tal conjunto comporta enunciados que vão de eventuais imprecações até os predominantes votos de restabelecimento. Com vistas a identificar algumas unidades e regularidades discursivas na dispersão dos textos midiáticos gerados pelo episódio mencionado, fundamentamo-nos na Análise do Discurso, derivada de Michel Pêcheux e seu grupo, e analisamos enunciados extraídos de um corpus constituído por textos que foram veiculados nos jornais Folha de São Paulo e Estado de São Paulo e na revista Veja.

Palavras-chave: Análise do Discurso, Lula, mídia, voz.

$1^{*} \mathrm{O}$ presente artigo apresenta resultados parciais do projeto de pesquisa "Discursos sobre a voz na mídia brasileira contemporânea", que é financiado pela Fundação de Amparo à Pesquisa do Estado de São Paulo (Processo FAPESP 2014/09947-3.) 
Abstract: This article aims to analyze the discourses produced by the Brazilian media concerning the throat cancer former President Luiz Inácio Lula da Silva suffered from in the year of 2011.The announcement of Lula's disease produced a large set of texts about the malady and the possible damages it could have done to his voice. This set includes a wide range of statements that go from eventual hostile curses to predominant best wishes for a full recovery. We propose to identify some discursive units and regularities in the dispersion of the media texts generated by the mentioned episode. To do so, based on the Discourse Analysis derived from Michel Pêcheux and his group, we intend to analyze statements extracted from a corpus consisted of texts which circulated in the Brazilian newspapers Folha de São Paulo and Estado de São Paulo, and in the weekly Brazilian magazine Veja.

Keywords: Discourse Analysis, Lula, media, voice.

Recebido em 11 de junho de 2014. Aprovado em 18 de novembro de 2014.

\section{Introdução}

Diante da pergunta "Teve medo de morrer?", que lhe foi dirigida pela jornalista Mônica Bergamo, durante a entrevista exibida no programa $T V$ Folha, veiculado pela TV Cultura, na noite do dia $1^{\circ}$ de abril de 2012, eis a resposta bastante significativa formulada pelo ex-presidente Luiz Inácio Lula da Silva: "Eu, eu, eu sinceramente, eu diferentemente de muita gente, eu tinha mais preocupação de perder a voz do que de morrer. Ou seja, porque eu, se eu perdesse esta voz, eu já tava morto; entende?". Lula, então, reitera dramaticamente o que tantos já haviam dito sobre os riscos que ele corria, caso ocorresse a perda de sua voz ou uma sua significativa alteração, motivada pelo câncer na laringe de que ele sofrera e do qual acabara de curar-se. Essa entrevista, por seu turno, foi ao ar quatro dias depois de Lula ter divulgado um vídeo pela internet no qual anunciava o restabelecimento de sua saúde, apresentava seus agradecimentos a todos que o apoiaram e proclamava sua volta às atividades políticas.

Após a divulgação de sua cura, Lula, então, revelava ter a exata medida da importância de sua voz. Com efeito, já desde o anúncio de 
sua doença, começaram a pulular os enunciados sobre os riscos que ela apresentava para sua voz. Em vários domínios e segmentos sociais, surgiram dizeres acerca da enfermidade do ex-presidente e de suas possíveis e nefastas sequelas: as ameaças à voz de Lula foram tema de conversas cotidianas, de mensagens em redes sociais na internet, de debates entre profissionais da saúde, de comentários da classe política, de notícias, crônicas e reportagens da mídia.

Muito provavelmente por essa razão, deu-se também a emergência de algumas análises desses textos que tematizaram o episódio e cuja circulação ocorreu em vários veículos da mídia. Por meio de um breve recenseamento, pudemos encontrar os trabalhos de Fausto Neto e Weschenfelder (2012), de Fortuna, Araújo e Oliveira (2012) e de Falcão (2012), que respectivamente se dedicaram: i) à interpretação da passagem do anúncio do câncer do ex-presidente, nele inclusa a antecipação dos efeitos da quimioterapia pela qual Lula passaria, realizados numa instância não midiática, a saber, o Instituto Lula, para os tradicionais veículos da mídia, destacando certos dissensos nos pontos de vista da cobertura midiática; ii) à demonstração de que os semanários Veja, Época, Isto é e Carta Capital construíram distintos "Lulas", em conformidade com aquela que já era sua linha editorial, e foram, ora mais, ora menos apoiados ou refutados pelos leitores de diferentes comunidades em seus portais on-line; e iii) à sustentação da hipótese, segundo a qual a cobertura da mídia, a despeito dos diversos pontos de vista de seus veículos, procedeu pela reiteração da estrutura mítica, qual seja, a "partida", com um alto índice de produção textual e intensa repercussão, a "iniciação", fase menos agitada da cobertura do relativamente longo processo de tratamento da doença, e o "retorno", em que se dá o anúncio da cura da enfermidade. Os três estudos caracterizam-se por sua inscrição no campo da comunicação. Além de especificidades de nosso corpus e de nossos objetivos, o trabalho que realizamos distingue-se daqueles por descrever formas linguísticas empregadas nos textos da mídia, dando-lhes uma interpretação discursiva. ${ }^{2}$

\footnotetext{
${ }^{2}$ Esta nossa análise toma como ponto de partida e desenvolve os resultados apresentados pelo projeto de Iniciação Científica "Poderes e perigos da voz: uma análise dos discursos da mídia sobre o câncer de laringe de Lula e suas sequelas”, desenvolvido por Giovana Moretti, sob nossa orientação. O desenvolvimento de sua pesquisa contou com o apoio da FAPESP (Processo 12/08546-0), que lhe concedeu uma bolsa de IC entre setembro de 2012 e agosto de 2013.
} 
Com base no princípio postulado pela Análise do discurso, derivada de Michel Pêcheux e seu grupo, de que há uma interdependência entre a constituição histórica, a formulação linguística e a produção dos sentidos na sociedade (PÊCHEUX, 2011, p. 73), nossa proposta consiste em interpretar alguns enunciados produzidos pela mídia brasileira acerca desse acontecimento discursivo. Por conta desse objetivo geral e refletindo sobre as constantes atribuições de poderes e perigos à voz de Lula, tentaremos identificar as posições assumidas pelos enunciadores, apreender os já ditos reiterados no bojo da constituição dos enunciados midiáticos e interpretar certas especificidades linguístico-históricas de cada um dos veículos da imprensa aqui considerados, focalizando particularmente o tratamento que dispensaram na construção desse acontecimento, entendido aqui como "ponto de encontro de uma atualidade e uma memória", como identificação a "filiações sócio-históricas" e "agitação" e "deslocamento em seu espaço" (PÊCHEUX, 1997a, p. 17, 56). ${ }^{3}$

Visando a esses objetivos, analisaremos uma série de enunciados provenientes de um corpus constituído de textos de vários gêneros discursivos (artigos, crônicas, reportagens e comentários de leitores), veiculados em edições diárias dos jornais Folha de São Paulo e Estado de São Paulo e em edições semanais da revista Veja, cuja circulação deu-se entre os dias 29 de outubro de 2011, data de anúncio do diagnóstico do câncer de laringe de que Lula foi acometido, e 29 de março de 2012, dia seguinte à divulgação do referido vídeo no qual o ex-presidente anunciou a cura de sua doença.

\section{A posição e as estratégias discursivas da Folha}

Tomemos inicialmente a coluna de Eliane Cantanhêde, publicada na edição de 30 de outubro de 2011 do jornal Folha de São Paulo, logo no dia seguinte à difusão da notícia da doença de Lula. Eis precisamente algumas das passagens do texto da colunista da Folha: "Uma das forças de Lula é a voz, a imensa, a impressionante capacidade de comunicação desse político inato que saiu de um casebre no interior do Nordeste e cativou o mundo. A voracidade política e as eleições municipais de 2012

\footnotetext{
${ }^{3}$ Trata-se aqui do próprio conceito de "discurso", ou seja, a presença e o funcionamento das relações de força da sociedade determinando a constituição e a formulação do que é dito por seus sujeitos, o que equivale ao que Orlandi $(1998$, p. 25, 31, 54) chama de "exterioridade constitutiva", de "forma material" e de "historicidade".
} 
serão decisivas para salvá-lo. Lula virou o que virou pela inteligência, o carisma e a voz. Ela não irá lhe faltar.”.

Um rápido exercício analítico do enunciado "Uma das forças de Lula é a voz", relacionando-o aos demais dessa sequência discursiva, às suas condições de produção e à posição de seu enunciador atesta que eles são produto de um discurso no qual se afirmam, ao mesmo tempo, a aptidão comunicativa de Lula, que, por sua vez, parece relacionar-se com dizeres sobre a suposta prática de boa parte políticos de falar muito bem e nada efetivamente fazer para transformação da sociedade, e seu gosto pelo poder, no pré-construído "A voracidade política", que produz na nominalização definida o efeito de que a avidez de Lula pelo poder é uma evidência incontestável. Além da voz, as outras "forças de Lula" são a "inteligência" e o "carisma": a primeira pode ser interpretada como senso de circunstância ou "esperteza" e a segunda, como ascendência que se exerce sobre outrem, mediante as imagens que o enunciador faz de si nas práticas discursivas e não discursivas. Ademais, há ainda a produção de um efeito de empatia, sob a forma de algo que é concomitantemente um voto de restabelecimento e uma fala peremptória e profética, que em tese se quer performativa, no último enunciado da sequência, passíveis de serem observados particularmente na expressão taxativa da negação e no tempo verbal, no futuro do presente.

Os sentidos produzidos aqui se alinham bastante bem àqueles produzidos em outros textos do mesmo jornal, porque provêm de um mesmo discurso: Lula é espontâneo e calculista. Depois de já ter sido anunciada a cura de seu câncer, o editorial da Folha do dia 31 de março de 2012 diz o seguinte, ao comentar a entrevista concedida às repórteres Cláudia Collucci e Mônica Bergamo pelo ex-presidente e exibida, conforme dissemos, no dia 1 de abril daquele ano:

Lula não é dos que optam pela sensaboria e pelo convencionalismo. Sua decantada capacidade de comunicar-se talvez tenha, no fundo, uma chave bastante simples para ser entendida. Quanto mais idiossincrático, individualizado e inconfundível o político, mais amplo, provavelmente, é o alcance de sua mensagem ao eleitorado. (...) Espontaneidade, de resto, nunca foi sinônimo de ausência de cálculo. (...) Político dos pés à cabeça, Lula é messiânico, demagógico, inconveniente, humano, simpático, calculista, esquivo, mas sobretudo real; Lula raras vezes pecou por esse aspecto. 
A voz como uma das forças do ex-presidente equivale uma vez mais nessa posição à sua "decantada capacidade de comunicarse", que, por seu turno, remete à ideia de tratar-se de um "político dos pés à cabeça", cujas características são: "messiânico, demagógico, inconveniente, humano, simpático, calculista, esquivo, mas sobretudo real". A polissemia dos adjetivos dotados em princípio de valor eufórico ("humano", "simpático" e "real") é ressignificada nas combinações e substituições com as predominantes qualificações disfóricas, tornando possível uma sua interpretação como falível, contraditório e dissimulado. Assim, a importância de sua voz está relacionada à sua habilidade comunicativa, que está a serviço de sua "voracidade política", cujo exercício prevê cálculo, demagogia e dissimulação.

Ainda em outros textos do jornal, mais precisamente na reportagem intitulada "Internautas usam doença para atacar Lula" publicada na edição do dia $1^{\circ}$ de novembro de 2011, encontram-se enunciados como os seguintes: "Os críticos usam o anonimato para debochar do estado de saúde do petista em redes sociais e em comentários em sites de notícias." e "Diante do tom agressivo de alguns leitores, a Folha.com chegou a suspender temporariamente os comentários em reportagens publicadas no fim de semana". Três dias antes, o colunista Gilberto Dimenstein já afirmara que havia ocorrido "uma enxurrada de ataques desrespeitosos, desumanos, raivosos, mostrando prazer com a tragédia de um ser humano", quando da publicação de textos na Folha, que anunciavam a doença de Lula e discorriam sobre ela. Assim, a postura do jornal constrói certa empatia com o sofrimento humano alheio e condena a desmesura desumana dos exaltados, o que lhe permite endossar alhures suas críticas à dimensão política do ex-presidente. Nesses textos, não há enunciados disfóricos em relação a Lula, uma vez que a dimensão do sujeito de quem se falava era exclusivamente a humana, desvinculada do âmbito que projetou nacionalmente o líder do PT, a saber, o campo político-partidário.

Prova disso é o texto de Daniel Roncaglia, publicado na Folha no dia 19 de fevereiro de 2012, no qual se expõe o acelerado ritmo de trabalho político de Lula, mesmo depois de ter sido diagnosticado com câncer e estar em pleno tratamento da doença. Segundo Roncaglia, Lula teve cerca de 51 encontros em três meses e meio, "a maioria deles (34) no hospital Sírio-Libanês, transformado temporariamente no seu 'escritório político"'. Seu texto apresenta alguns detalhes sobre esses encontros, mas o enunciado que é ali destacado consiste justamente numa citação do 
presidente do Instituto Lula e sócio do ex-presidente, Paulo Okamotto, que teria afirmado a seu respeito "É um animal político". O sentido produzido aqui nada tem de positivo, pois sua equivalência semântica na formação discursiva à qual se filia a Folha corresponde à "voracidade política" e a outros de seus correlatos, tais como "messiânico", "demagógico", "calculista" e "esquivo". Logo, o que poderia ser interpretado como dedicação ao trabalho e, com alguma condescendência, como luta pelo bem-estar do povo brasileiro produz o sentido de ambição desenfreada pela manutenção no poder.

Em suma, na Folha é possível observar a ênfase na crítica negativa que é dirigida a Lula, ao considerarmos o destaque dado pelo jornal à suposta forma pela qual o ex-presidente teria se valido de sua doença para auferir ganhos em sua vida política, sem descurar de apresentar a sensibilidade humana de seus enunciadores, indispensável no tratamento a ser dispensado a assuntos e situações delicados como o câncer de laringe do qual Lula, então, sofria. A condenação dos excessos "raivosos" e "desumanos" de internautas e mesmo de alguns leitores da Folha funciona como escusa para a crítica que parece ser ainda mais isenta e legítima, construindo uma ótima imagem de si de seus enunciadores, que pretensamente dizem o que precisa ser dito, ou seja, a pretensa verdade, de forma civilizada, honesta e madura.

\section{A posição e as estratégias discursivas do Estadão}

O jornal O Estado de São Paulo foi a publicação que mais se esmerou para produzir um efeito de imparcialidade, na medida em que supostamente anunciou e abordou a doença de Lula de maneira referencial, técnica e neutra. A primeira ocorrência da notícia deu-se na edição do dia 30 de outubro de 2011, sob a forma de uma chamada de primeira página do jornal, em que se lê: "O ex-presidente Luiz Inácio Lula da Silva foi diagnosticado ontem com um tumor na laringe, após exames realizados no Hospital Sírio-Libanês, em São Paulo.” As formas remissivas que retomam o referente são aparentemente destituídas de juízo de valor: "Ele", "o ex-presidente" e "Lula", bem como as demais informações a seu respeito: “(...) iniciará amanhã o tratamento quimioterápico, mas não precisará ficar internado.”, "deixou o hospital pouco depois das 20 horas, sem fazer declarações”. Merece, porém, menção o último período desse texto: "O câncer na laringe está associado ao tabagismo e ao consumo de álcool.". 
Em seu destacado texto de capa, o enunciador do Estadão não afirma de modo explícito, mas sugere que a enfermidade de Lula pode ser resultante de seu consumo de drogas lícitas. Já na reportagem que se encontra na página 10 do caderno "Política", outra causa da doença é aventada por Guido Mantega, filiado ao PT, ministro de seu governo e amigo de Lula: "Mantega contou que Lula vinha sentindo desconforto na fala, mas acreditava que isso se devia ao ritmo intenso de viagens e palestras dentro e fora do país." Ademais, a declaração do ministro é apresentada sob a forma de discurso indireto, marcado ainda pela modalização epistêmica não-asseverativa do verbo "acreditar" no imperfeito. Em suma, há uma flagrante distinção no modo de apresentação das duas posições discursivas: uma na qual se expressa a provável causa de uma enfermidade que deriva de um fato devidamente sabido e outra que é mostrada como uma conjectura favorável e comprometida, porque aventada por um amigo, a respeito daquela que é por ele entendida como a nobre e intensa dinâmica de trabalho da figura mais proeminente de seu grupo.

Também a referência manifesta à voz de Lula ali contida indica discretamente uma sua vaidade e ambição política, que seria bastante descabida naquele contexto, segundo a sugestão do enunciador do Estadão. O excerto em que se lê essa insinuação é o seguinte: "Hoff disse que, para preservar a voz dos pacientes, geralmente opta-se pela quimioterapia à cirurgia. 'Trata-se de uma conduta-padrão internacional nesses casos', explicou o oncologista. 'Foi uma decisão da equipe médica, e não do paciente, a fim de se preservar a laringe.”. Em conjunto, a afirmação de que a preservação da voz responde a uma conduta padrão adotada no tratamento da doença e a negação de que se tratasse de um pedido ou exigência de Lula a opção por essa conduta para ter não sua voz alterada ou perdida soam como denegação, ou seja, o procedimento foi escolhido justamente porque a voz de Lula é uma condição fundamental para sua atuação política.

Na edição do dia seguinte, isto é, de 31 de outubro de 2011, foi publicado um texto do jornalista Fernando Gallo, no qual se fala do início do tratamento de Lula e da suspensão das viagens que o ex-presidente faria nos próximos meses, afirmando-se ainda que a "necessidade de quimioterapia para combater o câncer de laringe o fez cancelar deslocamentos até o fim de janeiro". Tal como ocorre em outros textos do Estadão, aqui também identificamos vários enunciados que buscavam reproduzir o discurso médico, sob a forma de citações do 
clínico pessoal de Lula e diretor de cardiologia do hospital Sírio-Libanês, Roberto Kalil. Foram ali reproduzidas algumas passagens em que Kalil faz comentários sobre a quimioterapia e o estado de espírito de seu ilustre paciente: "tranquilíssimo", "bem-humorado" e "confiante" em relação ao tratamento. Além disso, de passagem, o médico afirmou que, na avaliação de sua equipe de oncologistas, "o ex-presidente não corre o risco de perder a voz". As falas de Kalil são ao mesmo tempo investidas de crédito, quando da menção a suas credenciais, e descreditadas em alguma medida, quando se acrescenta ao texto de Gallo a seguinte declaração do médico: seu encontro com Lula foi "uma visita de amigo". Há ainda nesse texto a reiteração de que "Lula não participou da decisão por um tratamento de quimioterapia" e que "descartou uma intervenção cirúrgica".

A "transparência de Lula" também volta a ser mencionada. Kalil afirmou que o ex-presidente "pediu aos médicos transparência com a sociedade", e sustentou que "foi o próprio Lula quem solicitou que descesse para falar com os jornalistas". No texto de Gallo, essa transparência não foi objeto de crítica explícita nem associada a usos políticos oportunistas por parte de Lula ou de seu partido. Por outro lado, imediatamente abaixo, na mesma página 7 do primeiro caderno do Estadão, ou seja, no caderno de Política, foi publicado o texto assinado pela jornalista Karina Toledo, cujo tema era também a previsão de recuperação de Lula. No texto de Toledo, é possível identificar outras informações médicas, mas o que lhe dá especificidade e tom mordaz é o pequeno trecho reproduzido a seguir, que foi destacado pelo próprio jornal e sobre o qual nos deteremos:

\footnotetext{
Desigualdades: Lula começa o tratamento dois dias depois de receber o diagnóstico de câncer. Pacientes do Sistema Único de Saúde (SUS) têm de esperar até seis meses para ter acesso à radioterapia. Mais de $80 \mathrm{mil} \mathrm{morrem} \mathrm{por} \mathrm{ano}$ antes de conseguir.
}

A partir de enunciados como esse são produzidos efeitos de que o jornal mostra à sociedade civil a disparidade entre o tratamento cheio de prerrogativas usufruído pela classe política brasileira e as frequentemente ruins condições oferecidas aos cidadãos comuns. Trata-se do que chamamos de "politização da mídia" (PIOVEZANI, 2003). O Estado de S. Paulo não apenas seria partidário dos que criticam o Governo do PT 
por conta das más condições do sistema de saúde do Brasil mas também seria uma das fontes com as quais esses críticos podem informar-se sobre as "desigualdades" do país. A versão dos fatos assim apresentada ressalta a alegada contradição entre o que dizem os petistas, em geral, e Lula, em particular, sobre a necessidade de diminuição das diferenças sociais no Brasil e os privilégios de que eles usufruem, diante da "mera informação" de que o ex-presidente teve um atendimento rápido e de qualidade num dos melhores hospitais do país: boa parte dos brasileiros certamente deveria ficar indignada com o abismo de tratamento dispensado ao cidadão comum e ao político poderoso cheio de vantagens, denunciado pelo Estadão. O destaque para o termo "desigualdades" ocorre, portanto, por conta da diferença de cuidados entre o ex-presidente e a maioria dos cidadãos comuns. Conforme o jornal, Lula é prova de que os brasileiros não recebem a mesma atenção médica, independentemente de seus cargos e posses, isto é, não são tratados de maneira igualitária. O efeito é ainda pior, uma vez que entre as principais palavras de ordem do PT é a busca da redução das desigualdades brasileiras. Assim, insinua-se que Lula diz algo e procede efetivamente em sentido contrário.

Na página seguinte da mesma edição, encontra-se a coluna de José Roberto de Toledo, intitulada "Lula, Dilma e o câncer". Nela ressalta-se que "a transparência" de Lula já destacada pelo jornal é ressignificada como estratégia política; o mesmo ocorrerá na "Carta ao leitor" da revista Veja, conforme mostraremos. Ecoa aqui, dada a condição patente do fenômeno, um dos postulados fundamentais da Análise do Discurso: "as palavras mudam de sentido ao passar de uma formação discursiva para outra" (PÊCHEUX, 2011, p. 73). A carga semântica eufórica de "transparência" é apagada e invertida, na medida em que passa a produzir no discurso midiático um efeito de maquiavelismo político: aproveitar a ocasião oferecida pela fortuna sem nenhuma restrição ética. Eis aqui o fragmento do texto no qual se constrói esse efeito: "Do ponto de vista da opinião pública, a doença tende a reforçar o mito (...). Nunca é bom subestimar a empatia do brasileiro por quem está perdendo, mas demonstra garra para virar o jogo. Lula intuiu isso ao dar transparência total à doença desde o diagnóstico." Desse modo, o colunista praticamente interdita o leitor de identificar-se com o sofrimento de Lula e condoer-se com a difícil situação pelo qual ele passava e ainda produz um protocolo de interpretação mediante o qual se deve conceber a empatia alheia que lhe for endereçada. 
Também em sua coluna da edição do dia 2 de janeiro de 2012, Toledo volta a discorrer sobre um uso político da enfermidade de Lula. O colunista apresenta, com o efeito de objetividade que deles decorrem, dados estatísticos e gráfico sobre as falas de Dilma desde o início de seu mandato, focalizando em particular aquelas nas quais a presidenta mencionou o nome do ex-presidente. A certa altura de seu texto, Toledo afirma que "depois de outubro, quando tornou-se público que o expresidente havia sido diagnosticado com um câncer na laringe, o nome de Lula voltou a aparecer com assiduidade nos discursos presidenciais". Não são aludidas manifestamente as razões pelas quais isso ocorreu; contudo, as relações entre esse e os demais enunciados dos textos do Estadão nos conduzem à seguinte e reiterada crítica: a doença de Lula estava, novamente, sendo usada como um apelo político, e dessa vez também pela presidenta que o sucedeu.

\section{A posição e as estratégias discursivas da Veja}

A revista Veja manifestou-se sobre o diagnóstico da doença de Lula pouco mais de uma semana depois de seu anúncio em outros veículos; o que se atribui evidentemente à sua periodicidade semanal. Já na própria capa da edição 2242, publicada no dia 9 de novembro de 2012, a revista apresenta a imagem de Lula e lhe consagra uma matéria completa sobre sua enfermidade. Ademais, novamente é possível que observemos a reiteração da estratégia discursiva que designamos como "politização da mídia" e que constatamos ser frequentemente empregada pela mídia brasileira em geral, qual seja, a autoproclamação do exclusivo poder de revelar o que supostamente estaria inacessível ao cidadão comum, em particular quando se trata de assuntos políticos: "Os bastidores da luta de Lula contra o câncer".

Formulada pela jornalista Adriana Dias Lopes, a matéria de capa da revista dá destaque ao diagnóstico da doença de Lula, a todos os procedimentos pelos quais o ex-presidente passou e também àqueles pelos quais ele ainda passaria para tratá-la. O texto, que começa descrevendo as comemorações do ex-presidente no dia de seu aniversário, explica detalhadamente a trajetória de Lula desde que começou a reclamar dos sintomas da moléstia, passando pela realização dos exames, até o diagnóstico e início de tratamento. Em consonância com esses expedientes, no intuito de produzir um efeito de neutralidade, uma vez 
que pretensamente aborda o fenômeno sob um prisma objetivo, técnico e informativo, o enunciador do texto precisa até mesmo as dimensões do tumor na laringe do político: "Com 3 centímetros de comprimento, 2 de largura e 2 de espessura, o tumor do ex-presidente ocupa quase metade da laringe".

Também é ali salientado o risco que o tumor e, principalmente, sua extração implicavam à voz de Lula. Tal risco é qualificado como a pior sequela que a enfermidade poderia lhe causar: "Nesses casos, a cirurgia costuma ser a primeira opção de tratamento: é rápida, e em um mês, em média, o paciente retoma suas atividades cotidianas. Em quadros como o de Lula, no entanto, a extração cirúrgica do tumor pode deixar sequelas graves. A pior delas é a perda da potência da voz - o que, para um político (e, em especial, um político como Lula), representaria uma tragédia". Aqui, identificamos a reafirmação de que a voz é uma das forças de Lula tanto na expressão da personalidade pública e privada quanto na atuação em sua vida política. A abertura dos parênteses e a formulação linguística ali contida não correspondem, como talvez se pudesse supor, a um fortuito acréscimo, mas são, antes, responsáveis por uma reorientação da interpretação. Neles, ainda que mais discretamente, ouvimos os ecos de outros dizeres sobre Lula e sua voz então produzidos pela mídia brasileira de grande circulação:

O presidente que cometeu mais gafes na história do Brasil conseguia quase sempre roubar a cena ao abrir a boca. (...) Sua voz rouca, com erros de português, metáforas de futebol e piados do povão, era o elo com a massa, na versão sindicalista exaltado ou do lulinha paz e amor. O Brasil teve outros oradores inflamados (...) que se expressavam com vigor também na escrita. Lula não. Exerce uma liderança oral. A maioria da população brasileira não domina a palavra escrita. (...) Num país assim, a voz é hipervalorizada como capital simbólico. Lula sempre falou demais. ${ }^{4}$

${ }^{4}$ Ruth de Aquino. A voz de Lula. Revista Época. Edição de 30 de março de 2012. Disponível em: <http://revistaepoca.globo.com/Mente-aberta/ruth-de-aquino/ noticia/2012/03/voz-de-lula.html>. 
A todas essas informações e opiniões em nada abonadoras agrega-se uma outra, que, por seu turno, produz a reinterpretação das primeiras contidas no texto de Veja: a causa da doença. Num box preto bastante destacado no canto superior esquerdo da página 81 dessa edição da revista, encontrase o seguinte enunciado: "As principais causas do câncer de laringe. Em relação a uma pessoa saudável, o risco da doença aumenta... 10 vezes com o tabagismo... 4 vezes com o consumo abusivo de bebida alcoólica." Depois de serem mencionados mais dois fatores de risco, acrescenta-se o comentário: "Os dois primeiros riscos são multiplicados. Assim, uma pessoa que fuma e bebe tem uma probabilidade quarenta vezes maior em relação a quem não tem os mesmos fatores de risco." Numa palavra, a insinuação de Veja é a de que Lula teve câncer porque bebe e fuma...

$\mathrm{Na}$ posição discursiva do enunciador da revista, facilmente constatamos o estabelecimento de relações de substituição e / ou de combinação entre "Lula" e "uma pessoa que fuma e bebe", construindo equivalências semânticas e encaixamentos sintáticos cujos sentidos são absolutamente desfavoráveis ao ex-presidente. À direita desse box, na mesma página, há uma foto da esposa de Lula, flagrada com um cigarro à boca, acompanhada da seguinte legenda: "DA JANELA FECHADA. Lula diz que largou o cigarro em 2010, mas sua mulher, Marisa, mantémse fiel ao vício, como se vê na foto de $1^{\circ}$. de novembro, dia em que o ex-presidente voltou para casa depois do início da primeira sessão de quimioterapia." Foto e legenda contrastam com a referida "transparência" apresentada por Lula, familiares e equipe médica quanto à doença e a seu tratamento. Eis o contraste produzido por Veja: enquanto a esposa tenta ocultar-se sorrateiramente sob a cortina da janela de seu apartamento, fiel antes ao vício que ao cônjuge, e o marido alega ter deixado de fumar, cujo pressuposto é o hábito vicioso e cuja veracidade é posta em xeque pelas estatísticas, a revista mostra o que de fato acontece. "Veja" o que realmente ocorre: "como se vê na foto"...

O último parágrafo do texto de Veja começa com os dois seguintes períodos: "A transparência com a qual o ex-presidente enfrenta a doença é admirável. Desde o momento em que soube do câncer, ele pediu aos médicos que não escondessem nada sobre seu estado clínico." Relacionase e contrasta com esses períodos e os ressignifica consideravelmente a sequência final do texto: 
No vídeo feito ainda no quarto 1125 do Sírio-Libanês, ao lado de Marisa, o ex-presidente disse estar preparado para enfrentar mais uma batalha e conta com a solidariedade de todos. Não perdeu também a oportunidade de resvalar no uso político da doença. Em tom messiânico, defendeu: "Precisamos continuar acreditando em nosso país. Temos de acreditar na nossa presidente. Sem perseverança, a gente não consegue nada. Afinal de contas, eu vim para a Terra para lutar e melhorar a vida de todo mundo. Estou doido para falar 'meus companheiros e companheiras' mais forte, mas não estou podendo..." Os brasileiros querem vê-lo restabelecido, mas não porque ele seja o fiador da estabilidade política ou do desenvolvimento do país. Lula é simplesmente um ser humano. Deveria bastar.

De modo análogo ao que demonstramos mediante análise de textos do Estadão, aqui também se dá uma grande reconfiguração semântica da "admirável transparência de Lula". No texto da revista, a franqueza de Lula desliza para "uso político da doença", para "tom messiânico", para "defesa" e, finalmente, para "é simplesmente um ser humano"; ser humano este, que, como os demais, precisa de compaixão e solidariedade em horas de grande sofrimento, mas que também erra e mente, principalmente ao afirmar que veio à Terra para, não humana, mas divinamente, "lutar e melhorar a vida de todo mundo". Se há, pois, alguma transparência, esta é sobredeterminada nesses textos pelo atribuído oportunismo político, pela dissimulação e pela desmesura generosa com que Lula constrói e veicula sua autoimagem.

De fato, os efeitos pretendidos no principal texto da revista encontram-se já em sua seção "Carta ao Leitor", da mesma edição 2242, intitulada "A transparência de Lula", na qual são erigidos alguns comentários positivos a respeito da atitude do ex-presidente ao informar francamente os cidadãos brasileiros a respeito de sua saúde, mediante comparações que depreciam outros líderes políticos, como Fidel Castro e Hugo Chavéz, por terem se valido de mentiras em suas "malfadadas experiências de totalitarismo tropical". O texto também relembra os casos da presidenta Dilma Rousseff e o câncer linfático de que sofreu em 2009, e do vice-presidente José Alencar, que lutou contra um câncer na região abdominal por mais de dez anos. Entre o relativo elogio e tais comparações, uma crítica sobressai ao final do texto: 


\begin{abstract}
Nesses casos, porém, as notas nefastas costumam vir das tentativas de aproveitamento político da doença. Esse papel feio foi desempenhado por Marco Aurélio Garcia, o mesmo flagrado tripudiando sobre as vítimas do acidente da TAM em São Paulo, que reagiu à notícia da doença de Dilma com a hoje tristemente famosa afirmação: "Isso vai render votos." (...) Lula quase escorregou em um vídeo feito por seu instituto na semana passada. $\mathrm{O}$ expresidente agradeceu adequadamente as manifestações de carinho recebidas e em seguida enveredou para a política partidária. Como se fiador fosse do atual governo, pediu ‘apoio' à presidente Dilma - cujos índices de popularidade, é bom lembrar, dispensam ajuda.
\end{abstract}

Podemos observar que a "voracidade política" de Lula está novamente mencionada e destacada no referido enunciado, uma vez que, segundo o texto, há um nefasto "aproveitamento político da doença", em meio ao qual o adequado agradecimento se "enveredou para a política partidária" e instaurou o ex-presidente na condição de "fiador" de Dilma Rousseff. Ainda que talvez não estivesse reivindicando diretamente para si o poder, Lula estaria usufruindo de sua enfermidade para dar continuidade aos planos políticos que ele próprio havia começado. De certa forma, o poder estaria (in)diretamente em suas mãos, e, como seria pressuposto pelo leitor ideal de Veja e explicitamente dito pelo autor do texto, Lula deu a entender - com ou sem intenção-, que estava fazendo uso de sua condição enferma como um apelo político para conseguir mais votos para Dilma; notamos aí a presença não só da voracidade política mas também de sua inteligência, ou "esperteza", perante uma situação desfavorável, que supostamente foi transformada de modo astuto em proveito político.

$\mathrm{Na}$ formação discursiva em que se produziu esse dizer, há um sensível desequilíbrio entre o "agradeceu adequadamente", por um lado, e as "notas nefastas", o "aproveitamento político da doença" e o "enveredou para a política partidária”. O valor eufórico, em princípio, presente na "adequação" do agradecimento esvai-se ante o caráter nocivo contido no fato de tirar proveito político-partidário que pretensa e indevidamente sobressai daquela que é considerada uma inescrupulosa conduta de Lula. Assim, conforme a posição aqui assumida, "as [sinceras] manifestações 
de carinho recebidas" pelo ex-presidente foram "recompensadas" com a ingratidão de quem só pretende manter-se dissimuladamente de um modo ou de outro no poder. Constatamos, portanto, que a polissemia contida num primeiro momento no título do "Carta ao leitor" da revista, a saber, "A transparência de Lula", vai-se dissolvendo à medida que equivale nas paráfrases estabelecidas no texto a "notas nefastas", "aproveitamento político" etc.

O recurso de supostamente reproduzir enunciação e enunciado alheios, que se alinham perfeitamente à posição do enunciador, com o proveito ainda de aí construir um efeito interativo, visto que pretensamente abre-se espaço para a espontânea manifestação do outro, é empregado por vários veículos midiáticos em suas sessões de carta dos leitores. Veja também se valeu desse mecanismo tanto para consolidar sua posição sobre Lula quanto para produzir os efeitos de interatividade e do livre direito de fala em uma mídia de grande repercussão nacional. Com mais forte razão, tais efeitos se produzem, em circunstâncias nas quais, em tese, o enunciador dá voz a posicionamentos antagônicos, entre os quais se encontra aquele que consiste no de seu adversário. Em sua edição 2243, publicada no dia 16 de novembro de 2011, a sessão "Carta dos Leitores" apresenta dois depoimentos que reverberam a matéria de capa da edição anterior sobre a doença do ex-presidente.

Eis abaixo a primeira dessas duas cartas:

Depois da divulgação da doença de Lula, algumas pessoas louvaram o seu suposto talento para o marketing, chegando a sugerir que o ex-presidente poderia ter 'inventado' um câncer para ganhar espaço na imprensa. A bizarrice de alguns comentários revelou uma faceta cruel do ser humano; às vezes somos rudes e monstruosos. Parabéns a VEJA pela abordagem correta dessa tragédia.

Mara Narciso Montes Claros, MG

Identificamos ali, de imediato, uma leitora "real", porque dotada de nome, sobrenome e procedência geográfica, cujo posicionamento parece ser exclusivamente favorável a Lula. Mediante a crítica endereçada à crueldade daqueles que o haviam acusado de beneficiar- 
se do diagnóstico da enfermidade para angariar maior visibilidade midiática ou até mesmo de ter "inventado" a doença com tal propósito, a leitora refere-se à rudeza e à monstruosidade que podem caracterizar eventualmente a condição humana. Inicialmente, Mara Narciso utiliza uma modalidade enunciativa que, em princípio, a inclui no rol dos que por vezes são "rudes e monstruosos". Contudo, de fato, estamos diante de um uso da primeira pessoa do plural, que não é, nem inteiramente inclusivo, nem completamente exclusivo (cf. BENVENISTE [1946] 2005, p. 256-8), uma vez que há no enunciado tanto uma inclusão do "eu', do "tu" e do "ele" no "nós" da condição humana, quanto a relativamente sutil exclusão do enunciador do conjunto daqueles que não apenas não se compadecem com o provável sofrimento de Lula, mas criticam-no virulentamente, a despeito de seu frágil estado de saúde, da "tragédia" que então o acometeu. A bizarrice, a rudeza, a crueldade e a monstruosidade são atribuições bastante disfóricas impingidas a um outro com o qual a enunciadora não se identifica e a quem ela reprova o comportamento.

$\mathrm{Na}$ carta da leitora, sua posição pró-Lula compreende, no entanto, certa nuance, porque seu enunciado é finalizado com seus votos de felicitação à revista, que, segundo a enunciadora, abordou de forma "correta" a doença do ex-presidente. Conforme demonstramos acima, na construção discursiva do acontecimento empreendida por Veja em sua edição anterior, são reiteradas as acusações a Lula pelo uso político que ele teria feito do câncer. Há, portanto, um aparente descompasso entre o que seriam duas vozes da enunciadora: uma que condena a crueldade contida nas acusações endereçadas ao aproveitamento político da doença por parte de Lula; e a outra que parabeniza o veículo midiático que as efetuou à sua maneira, ou seja, de modo manifesto, mas não demasiadamente agressivo. Cremos tratar-se, antes, de uma mesma voz que denuncia o que se lhe apresenta como a inconveniência e atrocidade dos insultos (em circunstâncias em que os sentimentos esperados são a empatia e a compaixão), feitos, aliás, em outras esferas de produção e circulação de discursos, e que ao mesmo tempo felicita o responsável por aquilo que lhe parece ser um tratamento correto do episódio, provavelmente porque desprovido de excessos nas acusações, dessa vez formuladas com a relativa sutileza exigida pela condição pública de seu enunciador. Por fim, não nos parece ser aleatório o fato de as felicitações encerrarem o enunciado. Os estudos retóricos e textuais já nos ensinaram que as orientações argumentativas de uma formulação linguística não 
passam incólumes pela ordem e disposição das coisas ditas: ao cabo da leitura da carta, os ecos de sua afirmação da "abordagem correta" de Veja sobre o caso continuarão reverberando.

Observemos a seguir a outra carta de leitor publicada nas mesmas sessão e edição da revista:

Não sou eleitora do senhor Lula, mas o respeito como ser humano, principalmente neste momento em que ele está enfrentando um câncer. Mas fiquei impressionada com o fato de sua esposa, dona Marisa Letícia, ter aparecido fumando na janela de seu apartamento, como mostra a foto publicada na página 81 da edição 2242. Cuidado, dona Marisa, pela senhora e pelo seu marido.

Martha M. X. Silva Sorocaba, SP

Alguns pontos que se ressaltam inicialmente no enunciado são a articulação entre a oração negativa e aquela que principia com a primeira ocorrência da conjunção adversativa e a ênfase na circunstância desfavorável em que se encontrava o ex-presidente. Com efeito, numa abordagem discursiva, a primeira forma linguística não corresponde somente a um advérbio de negação, mas trata-se de uma marca polifônica, cujo funcionamento consiste na simultaneidade e sobreposição de vozes, que justapõe a afirmação e a negação da condição de eleitora de Lula, realizadas por dois enunciadores distintos e que subsome a primeira à segunda. Ademais, o enunciado é a materialização de um processo de contra-identificação (PÊCHEUX, 1997b, p. 215-6) do sujeito do discurso com aqueles que produzem outro enunciado cujas produção e circulação seriam facilmente atestáveis e cuja presença encontra-se no interdiscurso: "Sou eleitor(a) de Lula"; sua contra-identificação é ainda reforçada pela forma de tratamento "senhor" anteposta a Lula, a quem muito frequentemente referimo-nos com a familiaridade do apoio ou da oposição a um nosso próximo, a alguém íntimo ou ao menos a uma pessoa que nos é muito conhecida. Essa contra-identificação orienta a articulação tal como foi ali empreendida entre não ser eleitor de alguém e respeitálo. Em princípio, de acordo com certa moral e algumas legislações, que comportam variantes, o respeito deve ser estendido a todos, inclusive, aos 
adversários e mesmo aos inimigos. Não é isso que parece ser afirmado no enunciado sob análise. Um simples e rápido exercício parafrástico é aqui esclarecedor:

"Sou eleitora de Lula, por isso o respeito."

"Eu o respeito, por isso sou eleitora de Lula."

"Não sou eleitora de Lula, logo não lhe devo nenhum respeito."

"Não lhe tenho nenhum respeito, por isso não sou eleitora de Lula."

"Não sou eleitora de Lula, mas o respeito (...)."

A relação adversativa que, distintamente das quatro primeiras formulações, articula as duas posições "Não sou eleitora de Lula" e "o respeito" deve ser relacionada com a sequência linguística que produz outro sentido: a locução adverbial de modo "como ser humano" e a oração subordinada adverbial temporal "principalmente neste momento em que ele está enfrentando um câncer". Uma vez mais, não se trata de formas gramaticais, mas de "forma material" (ORLANDI, 1998, p. 31-2); a primeira delas restringe o respeito à condição humana de Lula e pode-se inferir que tal respeito não se estende à sua atuação na vida política (esta, concebida exclusivamente, com base nessa posição, não merece respeito...), ao passo que a segunda funciona como uma especificação do sentimento mencionado: só a condição humana de Lula merece respeito e isso, em particular, em ocasião na qual se nutriria essa sensibilidade moral por qualquer membro de nossa espécie que estivesse passando por tão doloroso processo.

Já a segunda adversativa marca o contraste entre os dois sentimentos pretensamente experimentados e expressos pela enunciadora: a empatia e a indignação. Em princípio, a identificação afetiva com a dor alheia e a indisposição com o mau comportamento de outrem parecem dirigidas distinta e respectivamente a Lula, em sua condição de enfermo, e à sua esposa, que fuma quando, onde e próxima de quem não deveria. Se há relativamente tal contraposição, há também uma extensão de atributos negativos da segunda ao primeiro ou talvez uma indistinção entre seus vícios físicos e éticos, visto que a referência ao fumo remete à causa da doença de Lula, segundo a revista, e o fato de fazê-lo contínua e dissimuladamente é também alastrado de Marisa ao ex-presidente ou simplesmente compartilhado entre ambos. A alegada 
dissimulação não passa incólume, pois Veja "mostra" o que realmente se faz nos bastidores; a leitora, atenta e grata, o reconhece: a revista revelou com a foto publicada em edição e página precisas a impostura do casal. Enfim, a carta da leitora encerra-se com o que poderia ser interpretado como um amigável, respeitoso e preocupado conselho, mas, posto em relação com os demais enunciados da revista publicados nessas suas duas edições, cujo mote era o câncer de Lula, e com todos os demais que frequentemente dispensou ao ex-presidente, o último período consiste, antes, numa dupla e corrosiva advertência: não fume para não contrair a senhora também um câncer e para não agravar o de seu marido e não esconda seus vícios da sociedade brasileira, porque Veja os revelará. Ao longo da breve carta, ocorre a variação de predominância das modalidades enunciativas empregadas: a "elocutiva" e a "delocutiva", nos dois primeiros períodos; e a "alocutiva", ${ }^{5}$ no terceiro. Nesse último, a implicação e a interpelação do interlocutor explícito e aparente produzem tanto o efeito de certa hierarquia - um sujeito que não possui vícios e não mente pode / quer / deve repreender diretamente um outro que os possui e os dissimula-, quanto o endereçamento indireto, mas efetivo a seus interlocutores, ou seja, a outros leitores da revista, que podem aderir à e / ou intensificar sua identificação com a posição da enunciadora que faz o conselho-reprimenda-denúncia.

Em suma, as cartas das leitoras que Veja escolheu reproduzir, além dos efeitos de liberdade de expressão e interatividade auto-atribuídos, constroem a imagem de enunciadores que são generosos, humanos, sensíveis, etc., mas que, nem por isso, antes, ao contrário, deixam de lado seu senso crítico - criticidade, que, por seu turno, é sinônimo de adesão e identificação ao posicionamento da própria instituição midiática; aliás, exercem-na frequente e corrosivamente. Tudo se passa como se a revista dissesse o seguinte: Lula está doente, precisa de tratamento e merece se curar - uma vez que nem mesmo um ferrenho opositor de Lula, como é o caso de Veja, poderia afirmar publicamente outra coisa ante o sofrimento promovido por tão grave enfermidade. A revista expressa, assim, seu generoso compadecimento. Contudo, reitera que Lula, a despeito de

\footnotetext{
5"Os procedimentos enunciativos permitem àquele que fala colocar-se em cena (enunciação 'elocutiva'), implicar seu interlocutor em seu ato de fala (enunciação 'alocutiva') e apresentar o que é dito como se nenhum dos dois estivessem aí implicados (enunciação 'delocutiva') (CHARAUDEAU, 2005, p. 134).
} 
fazê-lo diferentemente de outros líderes políticos sul-americanos, está valendo-se de sua doença para se promover politicamente e para manter seu partido ou para manter-se ele próprio no Governo de municípios, estados e do próprio país. Eis aí, portanto, o que Veja estaria uma vez mais revelando a seus leitores: uma estratégia política oportunista.

\section{Considerações finais}

Ao tratar da voz de Lula por ocasião do anúncio de seu câncer de laringe, a letra impressa da grande mídia brasileira não falou da familiaridade com que ela é recebida pelos ouvidos brasileiros, sejam eles prosélitos ou opositores da atuação pública do ex-presidente, nem da potência política nela congregada, que permitiu talvez como "nunca antes na história deste país" ao pobre e ao trabalhador brasileiro falar e ser ouvido, ainda que muitíssimo aquém do que é preciso e do que lhe é de direito, tampouco da particularidade de seu timbre grave e áspero e de sua eloquência popular, em cujo encontro expressaram-se a concretude das dores da pobreza e o excelso de seus sonhos em suas ainda tímidas reivindicações. Antes, nesses textos da mídia nacional, verificamos a reiteração, em geral, de uma mesma orientação conservadora e das mesmas estratégias e recursos discursivos que visam a produzir o efeito de revelação das verdades e dos bastidores que, sendo supostamente inacessíveis aos membros comuns da sociedade, apenas nossos grandes jornais, revistas ou emissoras de tevê poderiam conhecer e nos transmitir, fazendo-o de modo neutro e imparcial. Além da repetição geral dessa posição, dessas estratégias e desses efeitos, constatamos algumas especificidades na construção midiática desse acontecimento decorrentes de aspectos singulares envolvidos nas condições de produção de seus textos.

Com efeito, não anunciamos uma doença tal como informamos um item de lista de compras de supermercado; não anunciamos um câncer tal como informamos um resfriado; e não anunciamos um câncer de um familiar, de um amigo ou da maior personalidade pública de nosso páis (evidentemente consideradas maiores ou menores similaridades e diferenças nesses anúncios) tal como informamos essa doença, quando sofrida por um ente em relação ao qual, em função das distâncias espacial, cronológica e / ou afetiva, somos indiferentes. Não há identidade de sentimentos entre a angústia ante um relativo e até mínino sofrimento 
de um próximo querido e o desinteresse pela morte de um "mandarim chinês". ${ }^{6}$ Um câncer de Lula, cujos riscos eram sua morte, a perda ou uma significativa alteração de sua voz, não poderia ser anunciado de qualquer maneira. Nossa análise dos textos da mídia que trataram dessa temática permitiu-nos depreender o que é dito em seus enunciados, o modo como são construídas suas enunciações e os efeitos que lhe são derivados. A empírica degeneração celular em parte da laringe de Lula consistiu principalmente num mote para a abordagem midiática de algumas pretensas facetas não virtuosas do ex-presidente, com as quais foi construído discursivamente um acontecimento, com base em retomadas, reformulações e silêncios da memória, fundamentados pelas filiações ideológicas de seus enunciadores.

O discurso da grande mídia brasileira materializado nos textos que trataram do câncer de Lula comporta identidades e diferenças em seus enunciados. Enquanto a Folha produziu: i) o deslocamento da "força da voz de Lula" para sua capacidade de comunicação e desta para voracidade política, que se vale do carisma, da demagogia e da dissimulação com vistas a manter-se no poder; ii) passagens textuais nas quais não há críticas disfóricas a Lula, uma vez que ali se tratava de focalizar a condição humana, e não política do sujeito que sofre gravemente; e iii) o efeito de empatia para com o sofrimento do enfermo, que compreendeu inclusive a explícita reprovação das manifestações acintosas de seus leitores no site do jornal; o Estadão: i) buscou empregar com frequência linguagem referencial e técnica, no intuito de construir um efeito de objetividade na divulgação das notícias em torno da doença do ex-presidente; ii) insinuou, ora mais, ora menos, explicitamente que o câncer era resultado do consumo de bebida alcóolica e de cigarro; iii) mencionou a pretensa vaidade de Lula, que estaria mais preocupado em não sofrer alterações em sua voz do que em salvar a própria vida; e iv) ressignificou a "transparência" de Lula, por não ter omitido seu câncer, ao cotejá-la com o tratamento médico privilegiado que o político usufruiu e ao derivá-la para o aproveitamento estratégico da doença para promover-se politicamente. Por seu turno, Veja: i) também se empenhou

\footnotetext{
${ }^{6}$ Trata-se aqui de uma alusão ao texto de Carlo Ginzburg (2001), no qual o historiador italiano discorre sobre "as implicações morais da distância", com base em referências como a alegoria da provável indiferença de um europeu das Luzes diante de morte de um mandarim chinês, tal como essa alegoria fora construída por Diderot.
} 
em produzir um efeito de neutralidade em sua cobertura do episódio, mediante certa constância na descrição de procedimentos médicos e de detalhes da enfermidade e do tumor; ii) aludiu ao grande risco que representaria para Lula a perda ou alteração de sua voz, uma vez que a estima pública gozada por ele dependeria de sua retórica popular, oral e vocal; iii) sugeriu igualmente que o câncer teria sido causado pelo consumo de álcool e tabaco; e iv) a franqueza com que o ex-presidente divulgou sua condição esteve a serviço do proveito político oriundo de sua grande e piedosa exposição midiática.

Em suma, eis aí aparentemente duas vozes: aquela da sensibilidade e da empatia humana e aquela da necessária crítica social. Contudo, essas vozes não estão equitativamente distribuídas, de modo a formar uma equilibrada polifonia. Aprendemos com Pêcheux (2011) que as formações discursivas determinam o dizer dos sujeitos de uma sociedade e com Foucault (1996) que não é qualquer sujeito que pode falar de qualquer coisa em qualquer circunstância. A força e o alcance do discurso são tamanhos que sua ação não se limita a determinar o que pode e deve ser dito, mas incide também e decisivamente sobre a formulação do dizer. Ao serem impelidos a falar do câncer de Lula, os veículos da grande mídia brasileira viram-se forçados a expressar certos repeito e compaixão, ou seja, foram compelidos a manifestar uma sensibilidade específica ante ao sofrimento humano. Isso, porém, não os impediu, antes, ao contrário, de lhe dirigir predominantemente uma série ampla de críticas que diziam respeito ao homem de vícios e ao político velhaco. Não se trata, pois, aí de polifonia, mas de uma compulsória e mínima presença de um sentimento benevolente, cuja função é a abertura do espaço para uma condenação política; trata-se, sim, conforme postula Orlandi (1989, p. 44), da tentativa de "produção da monofonia", dessa orquestração que visa à obtenção de "uma voz social homogeneizante que faz parte do mecanismo articulado entre o silenciamento e a injunção ao dizer, posta em prática por mediadores que distribuem socialmente os sentidos".

\section{Referências}

BENVENISTE, E. Estrutura das relações de pessoa no verbo. Problemas de linguística geral. vol. 1. Campinas: Pontes, 2005, p. 247-259.

CHARAUDEAU, P. Le discours politique: les masques du pouvoir. Paris: Vuibert, 2005. 256p. 
FALCÃO, C. C. Lula e o câncer: entre mitologias e midiatizações. In: CONGRESSO BRASILEIRO DE CIÊNCIAS DA COMUNICAÇÃO, 35., 2012, Fortaleza. Anais... 2012, p. 1-12. Disponível em: <www. intercom.org.br/papers/nacionais/2012>.

FAUSTO NETO, A.; WESCHENFELDER, A. Contendas de sentidos: estratégias de midiatização da doença do ex-presidente Lula. Animus (Revista Interamericana de Comunicação Midiática), vol. 11, n. 22, p. 246-271, 2012.

FORTUNA, B. S.; ARAÚJO, A. C. C.; OLIVEIRA, V. C. Análise da cobertura jornalística das revistas Veja, Carta Capital, Isto é e Época sobre a doença do ex-presidente Lula. In: Biblioteca Online de Ciências da Comunicação, p. 1-25, 2012. Disponível em: <www.bocc.ubi.pt/pag/ fortuna-araujo-oliveira-analise-da-cobertura-jornalistica.pdf $>$.

FOUCAULT, M. A ordem do discurso. São Paulo: Loyola, 1996. 79p.

GINZBURG, C. Matar um mandarim chinês: as implicações morais da distância. In: _. Olhos de madeira: nove reflexões sobre a distância. São Paulo: Cia. das Letras, 2001. p. 199-218.

ORLANDI, E. Silêncio e implícito (Produzindo a monofonia), In: GUIMARÃES, E. (Org.). História e sentido na linguagem. Campinas: Pontes, 1989. p. 39-46.

ORLANDI, E. Interpretação: autoria, leitura e efeitos do trabalho simbólico. Rio de Janeiro: Vozes, 1998. 150p.

PECHEUX, M. O discurso: estrutura ou acontecimento. Campinas: Pontes, 1997a. 68p.

PÊCHEUX, M. Semântica e discurso: uma crítica à afirmação do óbvio. Campinas: Editora da Unicamp, 1997b. 317p.

PÊCHEUX, M. Língua, linguagens, discurso, In: PIOVEZANI, C.; SARGENTINI, V. (Org.). Legados de Michel Pêcheux. São Paulo: Contexto, 2011, p. 63-75.

PIOVEZANI, C. Política midiatizada e mídia politizada: fronteiras mitigadas na pós-modernidade. In: GREGOLIN, M. R. (Org.). Discurso e mídia: a cultura do espetáculo. São Carlos: Claraluz, 2003. p. 49-64. 